\title{
Development of OCIPSE Learning Model to Increase Students' Scientific Creativity in Natural Science Learning
}

\author{
Rizqi $^{1}$, Prabowo ${ }^{2}$, Tjandra Kirana ${ }^{3}$ \\ 1Education Quality Assurance Agency of East Java, Surabaya, Indonesia \\ 2,3State University of Surabaya, Surabaya, Indonesia
}

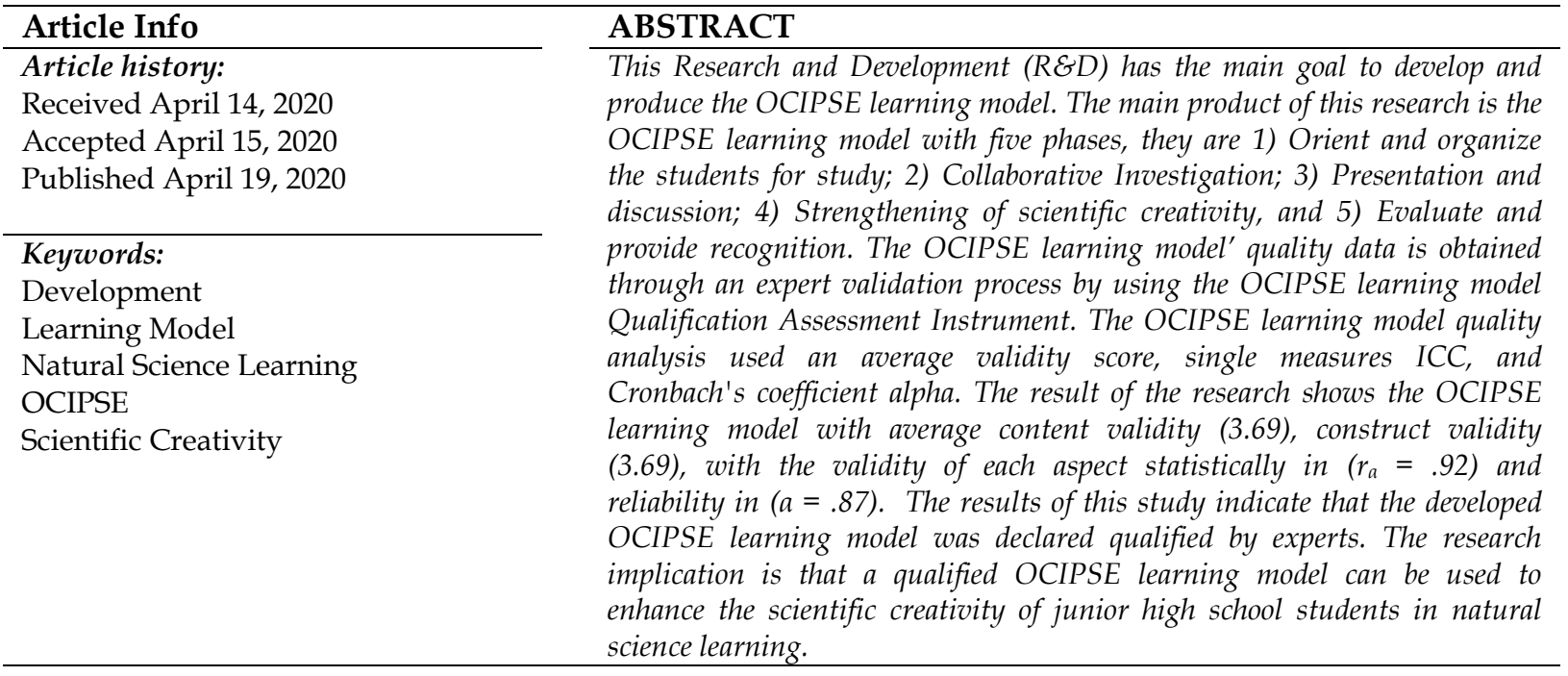

\section{INTRODUCTION}

Students are required to have superior competencies with various skills in the $21^{\text {st }}$ century including scientific creativity. The framework for $21^{\text {st }}$ century learning-based learning systems need to be prepared so that students can overcome various problems of life in the $21^{\text {st }}$ century that are more complex and must be owned by someone to survive in facing everyday life (Suyidno et al., 2018). Scientific creativity is needed as a provision for life. To anticipate the developments in the era of globalization, it is necessary to improve the quality of education in Indonesia, one of them is the implementation of the 2013 curriculum as an effort to prepare graduates who have the attitude of knowledge and various skills, including scientific creativity. This is stated in the Minister of Education and Culture Regulation number 68 year 2016 concerning the structure of Junior high school curriculum that the must-achieve competencies by Junior high school students through natural science learning include scientific creativity. Therefore, it is necessary to develop innovative models to increase the scientific creativity of junior high school students in natural science learning.

Scientific creativity is a thinking skill to produce new ideas or products that have scientific uses (Ayas \& Sak, 2014; Chin \& Siew, 2015; Hu \& Adey, 2010; Hu et al., 2013; Kang et al., 2015; Raj \& Saxena, 2016; Siew et al., 2014; Suyidno et al., 2018). The importance why scientific creativity must be owned and trained by students is because scientific creativity requires students to solve various real-life problems, adapt to the time, create creative and innovative ideas to achieve success in learning (Blascova, 2014; 
Dhir, 2014; Greiff et al., 2014; Latuconsina, 2014; OECD, 2014). The Indicators of scientific creativity include unusual uses, wall problems, product improvement, scientific imagination, problem-solving science, creatively experiment design, and creatively product design (Hu \& Adey, 2010; Hu et al., 2013).

The results of a preliminary study on teachers and students in Surabaya found that (1) teachers experienced limited time to develop learning models and learning tools in natural science learning that specifically increased the scientific creativity of Junior high school students (2 ) students still have difficulty in using scientific creativity, (3) scientific creativity of Junior high school students, in general, have not yet reached the value of 50 from a maximum value of 100, and (4) learning has not been based on scientific collaboration and scientific investigation. The fact that supports this preliminary study is the results of the PISA international study, which placed Indonesian students at the bottom in 2012 and 2015 studies (OECD, 2013; 2016). The composition of the tested PISA questions that were dominated by high-level thinking questions is still a weak point for Indonesian students, including the scientific creativity of junior high school students. The results of the preliminary research and the PISA results indicate that an innovative natural science learning model is needed to improve scientific creativity according to the character of junior high school students in Indonesia.

Learning models that can enhance the scientific creativity of junior high school students include the Problem Based Learning (PBL) model, the Collaborative Learning (CL) model, and the C3PDR learning model. The PBL model uses authentic and meaningful problems that students find as the starting point for acquiring new knowledge (Batdi, 2014; Imafuku et al., 2014; Stalker et al., Temel, 2014). The syntax of the PBL Model are (1) Directing students to problems, (2) Organizing students for learning, (3) Helping independent and group investigations, (4) Developing and presenting artifacts and exhibits, (5) Analyzing and evaluating problem-solving processes (Arends, 2012; Batdi, 2014; Moreno, 2010).

The strengths of the PBL model can improve the achievement of student learning outcomes, improve the collaborative ability of students, and presenting the results of investigations to the maximum can improve creative thinking skills, problem-solving skills, and mastery of physics contextually (Arends, 2012; Batdi, 2014; Imafuku et al., 2014; Moutinho et al., 2015; Sockalingam \& Schmidt, 2011; Stalker et al., 2014; Temel, 2014).

The literature review shows the weaknesses of PBL model that still need to be improved include: (1) The role of responsibility and collaboration of students is not maximal (Gorghiu et al., 2015); (2) Less linking with the nature of contemporary science and its applications (Moutinho et al., 2015). (3) Instructions are still not maximal, less trained to maximize scientific creativity (Nariman \& Chrispeels, 2015). (4) The collaboration does not require creative products and scientific imagination (Ersoy \& Başer, 2014). The results of the study on the PBL model above indicate the need for improvement and the importance of innovation in the PBL model to improve the scientific creativity of Junior high school students in natural science learning.

The Collaborative Learning (CL) model is student-centered learning in which collaborative groups build knowledge through working together to learn and solve a problem or produce a product (Burns et al., 2014; DeWitt et al., 2014; Laal \& Ghodsi, 2012). The advantages of collaborative learning include: (1) Enhancing the ability to solve problems collaboratively, reflecting contributions and interactions of success or 
failure in problem-solving activities (Laal \& Ghodsi, 2012); (2) Collaborative learning environment can improve student cooperation skills in solving problems in groups (Burns et al., 2014; Rogat \& Garcia, 2011); 3) Collaborative learning is proven to be able to enhance student creativity (Bettonia et al., 2015; Cocu et al., 2015; Laisema \& Wannapiroon, 2014; Maria et al., 2015).

CL model has main steps, they are: clarify goals and establish set, present information, organize student into learning teams, assist teamwork and study, test on the material, and provide recognition (Joyce et al., 2015; Laal \& Ghodsi, 2012; Okada et al., 2012). Small groups in CL offer many benefits that allow students to bring their own experiences into the learning process to improve active learning, encourage creativity, stimulate discussion, develop teamwork, improve communication and collaboration, and can enhance students' self-confidence (Barros, 2011).

The weaknesses of the CL Model could be examined from the results of other studies as follows (1) The weaknesses of grouping students in the CL Model is that students have difficulty in formulating hypotheses and become weak in managing the learning environment so student involvement in cooperation and interaction with others is very low (Eaton et al., 2015). (2) The CL model has not been optimal in encouraging students to complete assignments on time; it is difficult to unite differences of opinion in agreeing to the final decision, having difficulty in giving feedback and reflecting on the learning (Barros, 2011). (3) Nam (2014) suggests that students must be active in completing tasks so as not to become a negative attitude in collaboration. The results of the study on the CL model above indicate the need for improvement and importance of innovation in the CL model to increase the scientific creativity of junior high school students in natural science learning.

The C3PDR learning model, which stands for creative exploration, creative elaboration, creative modeling, the scientific practice of creativity, discussion and reflection, has been developed by Zulkarnaen et al. (2017) to improve the scientific creativity of junior high school students in natural science learning. The advantages of the C3PDR learning model (Zulkarnaen et al., 2017) include (1) in-depth understanding of each topic in the learning material, (2) improving the scientific creativity skills of junior high school students, (3) students have high motivation to follow the learning process, (4) students have broader ways of thinking, (5) students can work together, (6) students are more independent in learning and (7) students are accustomed to doing metacognition through reflection activities. Weaknesses and further research are needed to refine the C3PDR learning model (Zulkarnaen et al., 2017) include: (1) Further research needs to be carried out on the development of C3PDR learning devices for all selected materials at all grade levels in junior high school; (2) Broader implementation is strongly recommended to be conducted as a test of the ability of the C3PDR learning model in enhancing scientific creativity; (3) The n-gain results of junior high school students' scientific creativity are still in the moderate category, it needs to be increased in the high category through improvement especially the practicality of the C3PDR learning model; and (4) Improving the collaborative process because the essence of the C3PDR learning model is prioritizing collaborative work, but by design, it has not been maximized to enhance scientific creativity when using the C3PDR learning model. The results of the study on the C3PDR learning model above indicate the need for improvement and importance of innovation on the C3PDR learning model to improve the scientific creativity of junior high school students in natural science learning. Based on the described results of the study of the PBL, CL, and C3PDR models above, 
innovation will be carried out by developing an alternative natural science learning model to enhance the scientific creativity of junior high school students.

\section{General Background of Research}

Based on the literature review on the implementation of PBL, CL, and C3PDR models, scientific creativity indicators include unusual uses, wall problems, product improvement, creatively science problem solving, creatively experiment design, and creatively product design still needs to be trained and improved by junior high school students in natural science learning. The seven scientific creativity indicators are trained through each phase of the OCIPSE Learning Model by design. This research is categorized as Research and Development (R \& D). The subject of the OCIPSE is the junior high school students. The main product is the OCIPSE learning model in the form of an OCIPSE learning model book. The ECLIPSE learning model Book covers (a) the scope of OCIPSE learning model development, (b) the theoretical and empirical support of the OCIPSE learning model, (c) the plan and implementation of the OCIPSE learning model, (d) the management of the learning environment, (e) Implementation of the evaluation, (f) OCIPSE learning models: A final thought, and (g) bibliography.

\section{Problem of Research}

The main problem of this research is 'how the quality of OCIPSE learning model can enhance the scientific creativity of junior high school students in science learning?' The ECLIPSE learning model is declared to be qualified if they meet valid (content and construct) criteria and is reliable. To facilitate understanding of the OCIPSE learning model development, the sub-formulation of this research problem is as follows.

1. How rational is the development of the OCIPSE learning model?

2. How is the quality of the OCIPSE learning model?

\section{Research Focus}

This research is categorized as Research and Development ( $R$ \& D). The focus of this study is on the quality (content validity and construct validity) of the OCIPSE learning model, which can improve the scientific creativity of junior high school students in science learning. The purpose of this research is to produce a qualified model (which has been valid in content, construct and reliable). The focus of this research is on the validity of the qualified OCIPSE learning model by expert judgment that can improve the scientific creativity of junior high school students.

\section{METHOD OF RESEARCH}

\section{Instrument and Procedures}

The development of the OCIPSE learning model is based on the adaptation of the Wademan model research development design (Alfin et al., 2019; Pandiangan, 2017) as follows in Figure 1. 


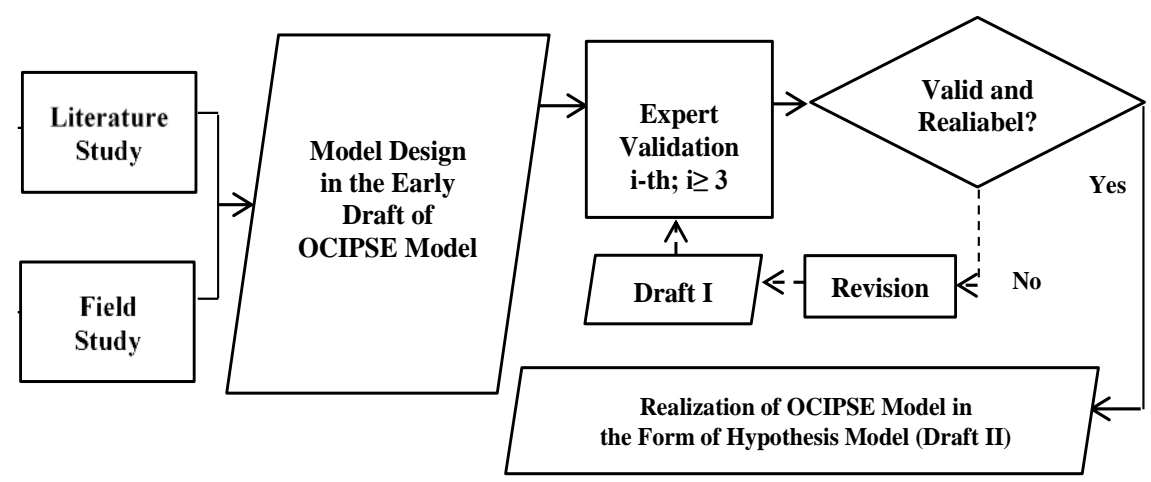

Figure 1. The research development stages of the OCIPSE learning model.

The preliminary research consists of literature studies and field studies. Literature studies and field studies are used to find related information (1) scientific creativity of junior high school students (2) learning models that can enhance scientific creativity, they are PBL, CL, and C3PDR models, (3) teaching and learning aspects that support scientific creativity that is seen from the students and teachers' perspective. The result of this preliminary study is the design model in the OCIPSE draft model. The OCIPSE learning model Quality Assessment Instrument was filled by education experts who reviewed and assessed the learning model developed by researchers during the FGD. It is used to obtain the OCIPSE learning model validity and reliability data. The used OCIPSE Quality Assessment Instrument model in this study has been declared valid and reliable by experts. The quality of the OCIPSE model was judged by the content validity and construct validity (Alfin et al., 2019; Erika et al., 2018; Nieveen et al., 2007). Content validity is an intervention and the design is based on state-of-the-art knowledge (Alfin et al., 2019; Erika et al., 2018; Nieveen et al., 2007). Construct validity is the intervention to fulfill logically designed (Alfin et al., 2019; Erika et al., 2018; Nieveen et al., 2007). The OCIPSE learning model was validated by three experts. The results of this validation are used as a reference to revise the OCIPSE learning model. When the validation results by 3 experts are declared valid and reliable, OCIPSE learning models are formed and can be used in learning to improve the scientific creativity of junior high school students.

\section{Data Analysis}

The quality of the OCIPSE learning model is calculated based on the results of evaluations by the validators. Validity score criteria include $3.30<$ Very Valid $\leq 4.00$; $2.30<$ Valid $\leq 3.30 ; 1.80<$ Less valid $\leq 2.30 ; 1.00 \leq$ Invalid $\leq 1.80$ (Alfin et al., 2019; Astutik \& Prahani, 2018; Erika et al., 2018). To strengthen the data analysis of validity and reliability of the OCIPSE learning models quality that has been developed, statistical tests are used, that is single measures Interpreter Coefficient Correlation (ICC) and Cronbach's coefficient alpha (Erika, Prahani, Supardi \& Tukiran, 2018; Malhotra, 2011; Pandiangan, 2017). The validity and reliability of OCIPSE learning model is determined by the validity formula $r_{a}=[($ Mean Square people - Mean Square residual) / (Mean Square people + (k-1) * Mean Square residual)] and Cronbach's alpha $a=\mathrm{k}_{\mathrm{a}}$ / [1+ (k-1) $\mathrm{r}_{\mathrm{a}}$ ] (Erika, Prahani, Supardi \& Tukiran, 2018; Malhotra, 2011; Pandiangan, 2017). OCIPSE learning model is said to be valid if $r_{\alpha}>r_{\text {table }}$ and invalid if $r_{\alpha} \leq r_{\text {table. }}$. 


\section{RESULTS AND DISCUSSION}

\section{Rationality of the Developed of OCIPSE Learning Model}

The OCIPSE learning model was developed to enhance the scientific creativity of Junior high school students who refer to John Dewey's problem-solving flow (Arends, 2012) and scientific creativity ( $\mathrm{Hu} \&$ Adey, 2010), and supported by positive dependence theory, complex cognitive process theory, cognitive psychology theory, cognitive-social constructivist theory, behavioral learning theory, and motivational learning theory (Arends, 2012; Bandura, 1977; Eggen \& Kauchak, 2013; Keller, 2010; Moreno, 2010; Slavin, 2011). The OCIPSE learning model maximizes the role of scientific collaboration in supporting the success of scientific inquiry and the task of scientific creativity.

The first phase aims to orient and organize students to learn. Teacher activities in the first phase include: (1) orients students to learn natural science through motivating students, conveying learning objectives, giving direction to the importance of scientific creativity. (2) The teacher organizes students to study natural science collaboratively by dividing students into heterogeneous groups (4-5 students) and dividing worksheet I: Collaborative Investigation. Student activities in the first phase include: (1) pay close attention to motivation, learning objectives and the importance of scientific creativity delivered by the teacher. (2) Students are guided by the teacher to join in groups (4-5 students) and receive worksheet I: Collaborative Investigation. This phase is supported by learning theory, including ARCS Theory (Attention, Relevance, Confidence, and Satisfaction) to arise curiosity and interest in learning, students must pay attention (Keller, 2010). Attention (Bandura, 1977), students must pay attention to the model that will be used as a model in the learning process (Moreno, 2010). Students are intrinsically motivated through an experience involving imagination and creativity (Eggen \& Kauchak, 2013). Positive interdependence, students need to have a positive dependency to achieve success in collaborative problem-solving processes (Moreno, 2010).

This first phase is reinforced by several studies, they are: (1) Teachers must be able to have a positive effect on student motivation in learning (Jones et al., 2013; Jones \& Vall, 2014). (2) The results of the study indicate that motivation can affect individual success (OECD, 2013). (3) The need for proper conditioning and preliminary preparation of student learning styles, self-efficacy, and academic intrinsic motivation in the learning process (Bembenutty et al., 2013), especially in the process of solving collaborative problems. (4) The purpose of the collaboration is the participation process of several people or groups who have a certain expertise in coordination and cooperation with high positive dependence in solving academic problems and daily life problems (OECD, 2015; Hesse et al., 2015). Based on the study of theoretical and empirical rationality, the first phase of the developed learning model was Orient and organize the students to study (Orienting and organizing students to study).

The second phase was designed to make active students in collaborative groups carry out Collaborative Investigation activities to train scientific creativity. Student activities in the second phase include: (1) accompanied by teacher guidance and positive interdependence with other students, the student participates in Collaborative Investigation activities by solving problems in the worksheet I: Collaborative Investigation to train scientific creativity. (2) Students are interdependent and work together to complete tasks in the worksheet I: Collaborative Investigation includes determining unusual uses, wall problems, product improvement, scientific imagination, problem-solving science, creatively experiment design, and creatively product design. 
Teacher activities in the second phase include: (1) guides students in Collaborative Investigation activities by solving problems in the worksheet I: Collaborative Investigation is an effort to train scientific creativity. (2) The teacher emphasizes aspects of scientific collaboration as long as students solve problems in the worksheet I: Collaborative Investigation. This second phase is supported by learning theories, among them are: Positive interdependence, students need to have a positive dependence on achieving success in collaborative problem-solving processes (Moreno, 2010). Using or changing previous knowledge and skills into creative products requires complex cognitive processes (Eggen \& Kauchak, 2013). Based on the cognitive constructivist theory by Piaget, each participant is actively involved in the process of acquiring information and constructing his or her knowledge (Arends, 2012). Vygotsky's social constructivist theory has two implications for social learning theory and ZPD (Slavin, 2011). In scientific creativity, students must understand information from the problems they face through individual cognitive processes.

This second phase was strengthened by several studies, they are: (1) Collaborative learning proved to be able to enhance students' creativity (Cocu et al., 2015; Maria et al., 2015; Laisema \& Wannapiroon, 2014; Bettonia et al., 2015). (2) Investigation can improve science process skills and scientific creativity (Zakar \& Baykara, 2014). (3) The need for an increase in the collaborative process because the essence of the C3PDR learning model prioritizes collaborative work, but by design it is not maximized to enhance scientific creativity when using the C3PDR learning model. (4) Skills for sharing perspectives are very important because a group cannot solve unless its members can understand concrete situations involving their collaborators (Trötschel et al., 2011). (5) The weakness in grouping students in CL Model is that students have difficulty in formulating hypotheses and being weak in managing the learning environment so that student involvement in cooperation and interaction among fellow students is very low (Eaton et al., 2015). Based on the study of theoretical and empirical rationality, the second phase of the developed learning model is Collaborative Investigation.

The third phase aims to internalize concepts, Scientific Creativity, and scientific collaboration with discussions and presenting the results in the Collaborative Investigation phase. Teacher activities in the third phase include: (1) teacher guides (teacher guidance if needed) students to discuss the results of Collaborative Investigation activities with their respective groups. (2) The teacher guides (teacher guidance if needed) students to internalize the concept, Scientific Creativity by presenting and communicating the results of group discussions. Student activities in the third phase include: (1) Students share views and actively participate in discussion activities as a result of Collaborative Investigation activities (teacher guidance if needed) with their respective groups. (2) Students internalize scientific concepts and creativity by presenting the results of group discussions (teacher guidance if needed). This third phase is supported by cognitive distribution theory: Conveying ideas to others can improve their understanding (Moreno, 2010). Dual coding theory (Slavin, 2011), information that is presented visually and verbally is better remembered than information that is only presented in one way. The process by which a student reaches expertise in his interactions with experts positive interdependence (Moreno, 2010, students need to have a positive dependency to achieve success in collaborative problem-solving processes.

This third phase is reinforced by several studies, they are: (1) Collaborative and scientific atmosphere is a key factor in scientific creativity (Hu et al., 2013). (2) The use 
of creative thinking techniques has been proven to increase the scientific creativity of students Hu et al. (2013); Al-Khatib (2012); Rizi et al. (2013); and Park (2011). (3) Lack of opportunity to provide realistic feedback to the quality of produced ideas; this reduces student motivation and impedes students' confidence in solving problems (Munro, 2011). Based on the study of theoretical and empirical rationality, the third phase of the developed learning model is Presentation and discussion.

The fourth phase aims to strengthen students' scientific creativity. Teacher activities in the fourth phase include: (1) The teacher provides further assignments as a strengthening process through worksheet II (Strengthening of scientific creativity) to improve the Scientific Creativity that students have. (2) If there are students who are still not maximally used scientific creativity in the follow-up assignments in worksheet II: Strengthening of scientific creativity, the teacher allows these students to work together and share their views with other students to improve social regulation and positive dependence between expert students and novice (expert students should not refuse when the novice student asks for help and guidance in completing the worksheet II). Student activities in the fourth phase include: (1) Students complete further assignments on the worksheet II (Strengthening of scientific creativity) as a strengthening process to improve Scientific Creativity that students already have. (2) If there are students who still have not maximally used scientific creativity in the followup assignments in worksheet II: Strengthening of scientific creativity, then with the teacher's permission the student is allowed to work together and share views with other students to improve social regulation and positive dependence between expert students and novices (beginners) (expert students should not refuse when the novice student asks for help and guidance in completing worksheet II).

This fourth phase is supported by the theory: Self-regulated learning, students are required to have the ability to control all aspects they have to successfully solve creative problems in collaborative groups (Moreno, 2010). Production (Bandura, 1977), students need new problems to be solved for the process of internalizing the knowledge they have (Moreno, 2010) and scaffolding (Slavin, 2011). Using or changing previous knowledge and skills into creative products requires complex cognitive processes (Eggen \& Kauchak, 2013). Positive interdependence, students need to have a positive dependency to achieve success in collaborative problem-solving processes (Moreno, 2010). Phase of increasing creativity. Worksheet II (Strengthening scientific creativity) can improve Scientific Creativity that has been supported by students. (2) If there are students who are still not maximally using scientific creativity in the advanced assignments in worksheet II: Strengthening scientific creativity, then the teachers got these students to work together and share their views with other students and expert students should not refuse when novice students ask for help and guidance in completing worksheet II). Worksheet II (Strengthening scientific creativity) as a strengthening process to improve Scientific Creativity that has been supported by students. (2) If there are students who are still not maximally using scientific creativity in the follow-up assignments in worksheet II: Strengthening scientific creativity, then with the permission of the teacher, students are allowed to work together and share opinions with other students, expert students and beginners, expert students should not refuse when novice (beginner) students ask for help and guidance in completing worksheet II).

This fourth phase is reinforced by several studies, they are: (1) Less linking with the nature of contemporary science and its application (Moutinho et al., 2015). (2) 
Instructions are still not maximal, less trained to maximize scientific creativity (Nariman \& Chrispeels, 2015). (3) Results of the Bembenutty et al. (2013); Zimmerman \& Schunk (2008) show that students who are unable to use self-regulated learning (SRL) in the PBL model will have low academic achievement and learning motivation. (4) The results of the scientific creativity n-gain of junior high school students are still in the moderate category need to be increased to the high category through improvement in the practicality of the C3PDR learning model (Zulkarnaen et al., 2017). Based on the study of theoretical and empirical rationality, the fourth phase of the developed learning model is the strengthening of scientific creativity and collaborative (Strengthening scientific creativity).

The fifth phase aims to evaluate and provide recognition for students. Teacher activities in the fifth phase include: (1) Teacher guides students to use social regulations to evaluate learning processes and outcomes related to scientific creativity. (2) The teacher provides recognition by giving appreciation to the performance of collaborative groups. (3) The teacher provides collaborative project assignments and reminds the material for further learning. Student activities in the fifth phase include: (1) Students use social regulation to evaluate learning processes and outcomes related to scientific creativity. (2) Students receive awards for collaborative group performance. (3) Students receive collaborative project assignments and material to be learned later. This fifth phase is supported by learning theory: Self-evaluation, students must be able to evaluate the process and results of scientific creativity and collaboration as a reflection for follow-up actions (Moreno, 2010). The final effect, the tendency for the items that appear at the end is easier to be remembered than other items (Slavin, 2011). Using or changing previous knowledge and skills into creative products requires complex cognitive processes (Eggen \& Kauchak, 2013). Students are intrinsically motivated through experience that involves imagination and creativity (Eggen \& Kauchak, 2013). Positive interdependence, students need to have a positive dependency to achieve success in collaborative problem-solving processes (Moreno, 2010).

This fifth phase is reinforced by several studies, they are: (1) Evaluation of others, ideas can improve problem-solving skills (Gregory et al., 2013). (2) Previous research results show that collaborative skills can be assessed on the contribution of individual, group, or organizational level (OECD, 2013). (3) The need for evaluation from the teacher to the process of students' investigation and problem-solving is an important component, without feedback, there will be obtained a little knowledge (Arends, 2012). (4) The CL model has not been optimal in encouraging students to complete assignments on time; it is difficult to unite differences of opinion in agreeing to the final decision, having difficulty in giving feedback and reflecting the learning process (Barros, 2011). Based on the study of theoretical and empirical rationality, the fifth phase of the developed learning model is to Evaluate and provide recognition.

By the researchers' argumentations that is supported by theoretical studies and empirical studies as described above, the OCIPSE learning model syntax was formed with five phases, they are 1) Orient and organize the students to study; 2) Collaborative Investigation; 3) Presentation and discussion; 4) Strengthening of scientific creativity, and 5) Evaluate and provide recognition. The name of the OCIPSE Learning Model is based on the five-phase acronym that has been described by the researcher. 
Table 1. Teacher and students activity in OCIPSE learning model.

Teacher Activity

Phase 1: Orient and organize the students to study

1. The teacher orientates students to learn science through motivating students, conveying learning objectives, giving direction to the importance of scientific creativity.

2. The teacher organizes students to study science collaboratively by dividing students into heterogeneous groups (4-5 students) and dividing worksheet I (Collaborative Investigation).

Phase 2: Collaborative Investigation

1. 1The teacher guides students in Collaborative Investigation activities by solving problems in worksheet I (Collaborative Investigation) as an effort to train scientific creativity.

2. The teacher emphasizes aspects of scientific collaboration as long as students solve problems in worksheet I (Collaborative Investigation).
1. Students pay close attention to motivation, learning objectives and the importance of scientific creativity delivered by the teacher.

2. Students are guided by the teacher to join in groups (4-5 students) and receive worksheet I (Collaborative Investigation).

1. With teacher's guidance and positive interdependence with other students, students participate in Collaborative Investigation activities by solving problems in worksheet I (Collaborative Investigation) as an effort to train scientific creativity.

2. Students share views and work together to complete tasks in the worksheet I (Collaborative Investigation) including unusual uses, wall problems, product improvement, scientific imagination, creatively problem-solving science, creatively experiment design, and creatively product design.

Phase 3: Presentation and discussion

1. The teacher guides (teacher guidance if needed) students to discuss the results of Collaborative Investigation activities with their respective groups.

2. The teacher guides (teacher guidance if needed) students to internalize the concept, scientific creativity by presenting and communicating the results of group discussions.

Phase 4: Strengthening of scientific creativity

1. The teacher provides further assignments as a strengthening process through worksheet II (Strengthening of scientific creativity) to enhance the scientific creativity that students have.

2. If there are students who are still not maximally using scientific creativity in the follow-up assignments in worksheet II: Strengthening of scientific creativity, the teacher allows these students to work together and share their views with other students to increase positive participation and dependence between expert students
1. Students share their views and actively participate in discussion activities as a result of Collaborative Investigation activities (teacher guidance if needed) by sharing positive views and dependencies with their respective groups.

2. Students internalize scientific concepts and creativity by presenting the results of group discussions (teacher guidance if needed).

1. Students complete advanced assignments on worksheet II (Strengthening of scientific creativity) as a strengthening process to enhance the scientific creativity that students have.

2. If there are students who are still not maximally using scientific creativity in the follow-up assignments in worksheet II: Strengthening of scientific creativity, then with the teacher's permission, the student is allowed to work together and share views with other students to increase participation and positive dependence between expert 
Teacher Activity

and novice students (expert students should not refuse when the novice student asks for help and guidance in completing worksheet II).

Phase 5: Evaluate and provide recognition

1. The teacher guides students to use social regulation to evaluate learning processes and outcomes related to scientific creativity.

2. The teacher provides recognition by giving appreciation for the performance of collaborative groups.

3. The teacher provides collaborative project assignments and reminds the material to be learned later.
Students Activity

students and novice (expert students should not refuse when the novice student asks for help and guidance in completing worksheet II).

1. Students use social regulation to evaluate learning processes and outcomes related to scientific creativity.

2. Students receive appreciation for the performance of collaborative groups with full positive dependence.

3. Students receive collaborative project assignments and material to be learned later.

\section{Quality of OCIPSE Learning Model}

The results of the OCIPSE learning model quality assessment are presented in Table 2. Table 2 shows that the validity of the content and reliability of the OCIPSE learning model includes: (1) OCIPSE Learning Model Development Needs, (2) State of the Art of OCIPSE Learning Model, (3) OCIPSE Learning Model Theory Support, (4) Planning and Implementation of OCIPSE Learning Model, (5) Learning Environment Management, and (6) Use of Advanced Evaluation Techniques have an average validation score of $3.80,3.67,3.67,3.67,3.67,3.67$ with very valid criteria and $r_{\alpha}$ is $.95, .92, .92, .92, .92, .92$, that are greater than $r$ table so that each component is declared valid. As for the reliability of each component in terms of value $\alpha$, everything is in the value of $.91, .87$, $.87, .87, .87, .87$, so that each component is declared reliable.

Table 2. Analysis result of OCIPSE learning model quality scoring.

\begin{tabular}{lcccccc}
\hline \multicolumn{1}{c}{ Component } & \multicolumn{5}{c}{ Validity and Reliability of OCIPSE learning } \\
model
\end{tabular}


Support of the OCIPSE Learning Model

3. Planning and Implementation of OCIPSE Learning Model

4. Learning Environment Management

$\begin{array}{lllll}3.67 & .92 & \text { Valid } & .87 & \text { Reliable }\end{array}$

$\begin{array}{lllll}3.67 & .92 & \text { Valid } & .87 & \text { Reliable }\end{array}$

$\begin{array}{lllll}3.67 & .92 & \text { Valid } & .87 & \text { Reliable }\end{array}$

5. The Use of Evaluation Techniques

6. OCIPSE Learning Model: A Final Thought

$\begin{array}{lllll}3.67 & .92 & \text { Valid } \quad .87 \quad \text { Reliable }\end{array}$

Table 2 shows that the construct validity and reliability of the OCIPSE learning model include: (1) OCIPSE Learning Model Overview, (2) Theoretical and Empirical Support of the OCIPSE Learning Model, (3) Planning and Implementation of OCIPSE Learning Model, (4) Learning Environment Management, (5) Evaluation Techniques, and (6) OCIPSE Learning Model: A Final Thought have an average validation score of $3.78,3.67,3.67,3.67,3.67,3.67$ with very valid criteria and $r_{\alpha}$ is .94, .92, .92, .92, .92, .92, that is greater than $r$ table so that each component is declared valid. As for the reliability of each component in terms of value $\alpha$, everything is in the value of $.92, .87, .87, .87, .87$, .87 , so that each component is declared reliable.

Tables 2 and Figure 2 illustrate that in general the content validity of the OCIPSE learning model has met the novelty and need for the development of the OCIPSE learning model to increase the scientific creativity of junior high school students. The novelty of this OCIPSE learning model is in the form of intervention. Interventions take precedence over the learning model to increase the scientific creativity of junior high school students. The results of this intervention are based on literary studies and studies on PBL, CL, and C3PDR Model. The OCIPSE Learning Model has learning outcomes that complement the shortcomings in the PBL, CL, and C3PDR models which are based on the results of the critical review of the literature that is presented in Table 3.

Table 3. Indicator of the PBL, CL, dan C3PDR learning results.

\begin{tabular}{|c|c|c|c|c|c|}
\hline $\begin{array}{l}\text { Learning } \\
\text { Results }\end{array}$ & Indicator & PBL & CL & C3PDR & OCIPSE \\
\hline Scientific & 1. Unusual uses & $\sqrt{ }$ & - & $\sqrt{ }$ & $\sqrt{ }$ \\
\hline Creativity & 2. Problem finding & $\sqrt{ }$ & - & $\sqrt{ }$ & $\sqrt{ }$ \\
\hline (Griffin \& & 3. Product improvement & $\sqrt{ }$ & - & $\sqrt{ }$ & $\sqrt{ }$ \\
\hline Care, 2015; & 4. Scientific imagination & $\sqrt{ }$ & - & $\sqrt{ }$ & $\sqrt{ }$ \\
\hline \multirow[t]{3}{*}{ NRC, 2015) } & 5. Creatively science problem solving & $\sqrt{ }$ & $\sqrt{ }$ & $\sqrt{ }$ & $\sqrt{ }$ \\
\hline & 6. Creatively experiment design & $\sqrt{ }$ & - & $\sqrt{ }$ & $\sqrt{ }$ \\
\hline & 7. Creatively product design & $\sqrt{ }$ & - & $\sqrt{ }$ & $\sqrt{ }$ \\
\hline \multicolumn{2}{|c|}{$\begin{array}{l}\text { Scientific Creativity Task (Gregory, Hardiman, } \\
\text { Yarmolinskaya, Rinne, \& Limb, 2013) }\end{array}$} & - & - & $\sqrt{ }$ & $\sqrt{ }$ \\
\hline \multicolumn{2}{|c|}{$\begin{array}{l}\text { Collaborative are proven to be able to improve } \\
\text { students' creativity (Cocu, Pecheanu \& Susnea, 2015; } \\
\text { Maria, Dimitris, Garifallos, Athanasios, \& } \\
\text { Roumeliotis, 2015; Laisema \& Wannapiroon, 2014; } \\
\text { Bettonia, Bernharda \& Bittela, 2015). }\end{array}$} & $\sqrt{ }$ & $\sqrt{ }$ & $\sqrt{ }$ & $\sqrt{ }$ \\
\hline \multicolumn{6}{|c|}{ Noted: $(\sqrt{ })=$ Available; $(-)=$ Unavailable; 1 : Phase 1 Orient and organize the students to study; 2 : Phase 2} \\
\hline
\end{tabular}


The construct validity of the OCIPSE learning model has shown consistency between phases in the model syntax, consistency between model components, and consistency between model and underlying theories. OCIPSE learning model has five syntaxes, they are 1) Orient and organize the students to study; 2) Collaborative Investigation; 3) Presentation and discussion; 4) Strengthening of scientific creativity; dan 5) Evaluate and provide recognition. These five phases have been designed to be interconnected with each other. The results of the validation process findings analysis show that the OCIPSE learning model is qualified (has been valid in content and constructs and reliable). The results of previous research showed that product development (teaching and learning model) quality (valid, practicality, and effective) can be used in learning to enhance the learning outcomes (Alfin et al., 2019; Astutik \& Prahani; 2018; Erika et al., 2018; Evendi et al., 2018; Hunaidah et al., 2018; Pandiangan et al., 2017; Sari et al., 2018; Siswanto et al., 2018; Yunus et al., 2017). Therefore, based on the above description, the review of all aspects of the OCIPSE learning model quality assessment, it shows that the OCIPSE learning model is qualified (already valid in content and constructs and reliable) so that it can be used as a solution to increase the scientific creativity of junior high school students.

\section{CONCLUSIONS}

The OCIPSE learning model is a learning activity that is specifically designed by maximizing the role of scientific collaboration in supporting the success of scientific inquiry and the task of scientific creativity. The main objective of the OCIPSE learning model is to increase the scientific creativity of junior high school students in science learning. OCIPSE learning model has five phases: 1) Orient and organize the students to study; 2) Collaborative Investigation; 3) Presentation and discussion; 4) Strengthening of scientific creativity, and 5) Evaluate and provide recognition. The OCIPSE research result shows the model has average content validity (3.69), construct validity (3.69), with the validity of each aspect statistically in $\left(r_{\alpha}=.92\right)$ and reliability in $(\alpha=.87)$. The results of this study indicate that the developed OCIPSE learning model was declared qualified by experts. The research implication is that a qualified OCIPSE learning model can be used to enhance the scientific creativity of junior high school students in natural science learning. Further research that can be done is to prove the quality of the OCIPSE learning model in terms of practicality and effectiveness to increase the scientific creativity of junior high school students in natural science learning.

\section{ACKNOWLEDGMENTS}

Thank you to the Education Quality Assurance Agency of East Java for supporting and funding this research.

\section{REFERENCES}

Alfin, J., Fuad, A.Z., Nur, M., Yuanita, L., \& Prahani, B.K. (2019). Development of group science learning (GSL) model to improve the skills of collaborative problem solving, science process, and self-confidence of primary schools teacher candidates. International Journal of Instruction, 12(1), 1-18.

Al-khatib, B.A. (2012). The effect of using brainstorming strategy in developing creative problem solving skills among female students in princess alia university college. American International Journal of Contemporary Research, 2(10), 29. 
Arends, R.I. (2012). Learning to teach. New York: Mc.Graw-Hill.

Astutik, S., \& Prahani, B.K. (2018). The practicality and effectiveness of collaborative creativity learning (CCL) model by using PhET simulation to increase students' scientific creativity. International Journal of Instruction, 11(4), 409-424.

Ayas, M.B., \& Sak, U. (2014). Objective measure of scientific creativity: Psychometric validity of the creative scientific ability test. Thinking Skills and Creativity, 13, 195205.

Bandura, A. (1977). Self-efficacy: Toward unifying theory of behavioral change. Psychological Review, 84(2), 191-215.

Barros, E.H. (2011). Collaborative learning in the translation classroom: Preminary survey results. The Journal of Specialized Translation, 1(16), 42-60.

Batdi, V. (2014). The effects of problem based learning approach on students' attitude levels: A meta-analysis. Educational Reseearch Review, 9(9), 272-276.

Bembenutty, H., Cleary, T., \& Kitsantas, A., (2013). Applications of self-regulated learning applied across diverse disciplines: A tribute to Barry J. Zimmerman. Charlotte, NC: Information Age Publishing.

Bettonia, M., Bernharda, W., \& Bittela, N., (2015). Collaborative creativity with eCiC. Procedia - Social and Behavioral Sciences, 174, 3925-3932.

Blascova, M. (2014). Influencing academic motivation, responsibility and creativity. Procedia - Social and Behavioral Sciences, 159, 415-425.

Burns, M., Pierson, E., \& Reddy, S. (2014). Working together: How teachers teach and students learn in collaborative learning environments. International Journal of Instruction, 7(1), 17-32.

Chin, M. K., \& Siew, N.M. (2015). The development and validation of a figural scientific creativity test for preschool pupils. Creative Education, 6, 1391-1402.

Cocu, A., Pecheanu, E., \& Susnea, I. (2015). Stimulating creativity through collaboration in an innovation laboratory. Procedia - Social and Behavioral Sciences, 182, 173 - 178.

DeWitt, D., Siraj, S, \& Alias, N. (2014). Collaborative mlearning: A module for learning secondary school science. Educational Technology E Society, 17(1), 89-101.

Dhir, T. (2014). Problem solving ability and science process skills as the influential factors of scientific creativity. International Journal of Research Pedagogy and Technology in Education Movement Sciences, 2(4), 11-17.

Eaton, G.V., Clark, D.B., \& Smith, B.E. (2015). Patterns of physics reasoning in face to face and online forum collaborative around a digital game. International Journal of Education Research, 3(1), 205-216.

Eggen, P.D., \& Kauchak, D.P. (2013). Educational psychology: Windows on clasrooms. New Jersey: Pearson.

Erika, F., Prahani, B.K., Supardi, Z.A.I., \& Tukiran. (2018). Development of a graphic organizer-based argumentation learning (GOAL) model for improving the ability to argue and self-efficacy of chemistry teacher candidates. World Transaction on Engineering and Technology Education, 16(2), 179-185.

Ersoy, E., \& Başer, E. (2014). The effects of problem-based learning method in higher education on creative thinking. Procedia-Social and Behavioral Sciences, 116, 3494 3498.

Evendi, Susantini, E., Wasis, \& Prahani, B.K. (2018). Improving students' scientific asking skills through the implementation of question webs based learning model. Journal Physics: Conference Series, 1108, 012037. 
Gorghiu, G., Draghicescu, L.M., Cristea, S., Patrescu, M., \& Gorghiu, L.M. (2015). Problem-based learning: An efficient learning strategy in the science lessons context. Procedia-Social and Behavioral Sciences, 191, 1865-1870.

Gregory, E., Hardiman, M., Yarmolinskaya, J., Rinne, L., \& Limb, C. (2013). Building creative thinking in the classroom: From research to practice. International Journal of Educational Research, 62, 43-50.

Greiff, S., Wustenberg, S., Csapo, B., Demetriou, A., Hautamaki, A., Graesser, A.C., \& Martin, R. (2014). Domain-general problem solving skills and education in the 21st century. Educational Research Review, 13, 74-83.

Griffin, P., \& Care, E. (2015). Assessment and teaching of $21^{\text {st }}$ century skills: Methods and approach. New York: Springer.

Hesse, F., Care, E., Buder, J., Sassenberg, K., \& Griffin, P.A. (2015). Framework for Teachable Collaborative Problem Solving Skills. In P. Griffin and E. Care (Eds.), Assessment and teaching of $21^{\text {st }}$ century skills: Methods and approach. Dordrecht: Springer.

Hu, W., \& Adey, P. (2010). A scientific creativity test for secondary school students. International Journal of Science Education, 24(4), 389-403.

Hu, W., Wu, B., Jia, X., Yi, X., Duan, C., \& Meyer, W. (2013). Increasing student's scientific creativity: The "learn to think" intervention program. The Journal of Creative Behavior, 47(1), 3-21.

Hunaidah, Susantini, E., Wasis, Prahani, B.K., \& Mahdiannur, M.A. (2018). Improving collaborative critical thinking skills of physics education students through implementation of CinQASE learning model. Journal Physics: Conference Series, $1108,012101$.

Imafuku, R., Kataoka, R., Mayahara, M., Suzuki, H., \& Saiki, T. (2014). Students' experiences in interdisciplinary problem-based learning: A discourse analysis of group interaction. Interdisciplinary Journal of Problem-based Learning, 8(2), 1-19.

Jones, B. D., Epler, C. M., Mokri, P., Bryant, L. H., \& Paretti, M. C. (2013). The effects of a collaborative problem-based learning experience on students' motivation in engineering capstone courses. Interdisciplinary Journal of Problem-Based Learning, 7(2), 1-10.

Jones, H.M.B., \& Vall, O.C. (2014). Preparing special educators for collaboration in the classroom: Pre service teachers' beliefs and perspectives. International Journal of Special Education, 29(1), 1-12.

Joyce, B., Weil, M., \& Calhoun. (2015). Models of teaching. New York: Pearson Education Inc.

Kang, D., Park, J., \& Hong, H. (2015). Changes in the number of ideas depending on time when conducting scientific creativity activities. Journal of Baltic Science Education, 14(4), 448-459.

Karantzas, C.G., Fitness, J., Michelle, R., Avery, R.M., Macfarlane, S., Mussap, A., Tooley, G., \& Hazelwood, Z. (2013). Enhancing critical analysis and problemsolving skills in undergraduate psychology: An evaluation of a collaborative learning and problem-based learning approach. Australian Journal of Psychology, 65, 38-45.

Keller, M.J. (2010). Motivational design for learning and performance the ARCS model approach. USA: Springer.

Laal, M., \& Ghodsi, M. S. (2012). Benefits of collaborative learning. Procedia Social and Behavioral Science, 31, 486-490. 
Laisema, S., \& Wannapiroon, P. (2014). Design of collaborative learning with creative problem-solving process learning activities in a ubiquitous learning environment to develop creative thinking skills. Procedia-Social and Behavioral Sciences, 116, 3921-3926.

Latuconsina, H. (2014). Pendidikan kreatif, menuju generasi kreatif dan kemajuan ekonomi kreatif di Indonesia. Jakarta: Gramedia Pustaka Utama.

Malhotra, N.K. (2011). Review of marketing research: Special issue-marketing legends. New York: Emerald Group Publishing Limited.

Maria, T., Dimitris, P., Garifallos, F., Athanasios, G., \& Roumeliotis, M. (2015). Collaboration learning as a tool supporting value co-creation, evaluating students learning through concept maps. 4th World Conference on Educational Technology Researches, WCETR-2014, Procedia - Social and Behavioral Sciences, 182, 375-380.

Moreno, R. (2010). Educational psychology. New York: Jhon Wiley \& Sonc.

Moutinho, S., Torres, Joana, T., Fernandez, I., \& Vasconcelos, C. (2015). Problem-based learning and nature of science: A study with science teachers. Procedia-Social and Behavioral Sciences, 191, 1871-1875.

Munro, J. (2011). Insight into the creativity process: The stage models of creativity. Australia: The University of Melbourne.

Nam, H.N. (2014). Utilizing the active and collaborative learning model in the introductory physics course. Journal of Education and Learning, 3(3), 108-124.

Nariman, N., \& Chrispeels, J. (2015). PBL in the era of reform standards: Challenges and benefits perceived by teachers in one elementary school. Interdisciplinary Journal of Problem-Based Learning, 10(1), 1-16.

Nieveen, N., McKenney, S., \& van. Akker. (2007). Educational design research. New York: Routledge.

OECD. (2013). PISA 2015 collaborative problem solving framework. Washington: OECD Publishing.

OECD. (2014). PISA 2012 results: Creative problem solving: Student's skills in tackling reallife problems (Volume V), PISA. Publishing: OECD.

OECD. (2015). OECD Programme for International Student Assessment 2015. Washington: OECD Publishing.

OECD. (2016). PISA 2015 Result in Focus. Washington: OECD Publishing.

Okada, A., Connolly, T., \& Scott, J.P. (2012). Collaborative learning 2.0: Open educational resources. NY: The Open University.

Pandingan, P. (2017). Model physics independent learning dalam face to face tutorial untuk meningkatkan keterampilan pemecahan masalah fisika dan keterampilan belajar mandiri mahasiswa pada pendidikan terbuka dan jarak jauh. Surabaya: Pascasarjana Unesa.

Pandiangan, P., Sanjaya, M.G.I., \& Jatmiko, B. (2017). The validity and effectiveness of physics independent learning model to improve physics problem solving and selfdirected learning skills of students in open and distance education systems. Journal of Baltic Science Education, 16(5), 651-665.

Pandingan, P. (2017). Model physics independent learning dalam face to face tutorial untuk meningkatkan keterampilan pemecahan masalah fisika dan keterampilan belajar mandiri mahasiswa pada pendidikan terbuka dan jarak jauh. Surabaya: Pascasarjana Unesa.

Park, J. (2011). Scientific creativity in science education. Journal of Baltic Science Education, 10(3), 144-145.

Raj, H., \& Saxena, D.R. (2016). Scientific creativity: A review of researches. European Academic Research, 4, 1122-1138. 
Rizi, C.E., Najafipour, M., Haghani, F., \& Dehghan, S. (2013). The effect of the using the brainstorming method on the academic achievement of students in grade five in Tehran elementary schools. Procedia-Social and Behavioral Sciences, 83, 230 - 233.

Rogat, K.T., \& Garcia, L.L. (2011). Socially shared regulation in collaborative groups: An analysis of the interplay between quality of social regulation and group processes. Cognition and Instruction, 29(4), 375-415.

Sari, A.S.D., Prahani, B.K., Munasir, \& Jatmiko, B. (2018). The improvement of students' physics problem solving skills through the implementation of PO2E2W learning model assisted PhET media. Journal Physics: Conference Series, 1108, 012024.

Siew, N.M., Chong, C.L., \& Chin, K.O. (2014). Developing a scientific creativity test for fifth graders. Problems of Education in the 21 $1^{\text {st }}$ Century, 62(1), 109-123.

Siswanto, J., Susantini, E., \& Jatmiko, B. (2018) Multi-representation based on scientific investigation for enhancing students' representation skills. Journal Physics: Conference Series, 983, 012034.

Siswanto, J., Susantini, E., \& Jatmiko, B. (2018). Practicality and effectiveness of the IBMR teaching model to improve physics problem solving skills. Journal of Baltic Science Education, 17(3), 381-394.

Slavin, E. R. (2011). Educational psychology: Theory and practice. Boston: Pearson.

Sockalingam, N., \& Schmidt, H.G. (2011). Characteristics of problems for problem-based learning: The students' perspective. Interdisciplinary Journal of Problem-Based Learning, 5(1), 6-33.

Stalker, S.L., Cullen, T., \& Kloesel, K. (2014). Using PBM to prepare educators and emergency managers to plan for severe weather. Interdisciplinary Journal of Problem-Based Learning, 9(2), 1-9.

Suyidno, S., Nur, M., Yuanita, L., Prahani, B.K., \& Jatmiko, B. (2018). Effectiveness of creative responsibility based teaching (CRBT) model on basic physics learning to increase student's scientific creativity and responsibility. Journal of Baltic Science Education, 17(1), 136-151.

Temel, S. (2014). The effects of problems based learning on pre service teachers's critical thinking dispotitions and perceptions of problems solving ability. South African Journal of Education, 34(1), 1-20.

Trötschel, R., Hüffmeier, J., Loschelder, D.D., Schwartz, K., \& Gollwitzer, P.M. (2011). Perspective taking as a means to overcome motivational barriers in negotiations: When putting oneself into the opponent's shoes helps to walk toward agreements. Journal of Personality and Social Psychology, 101(4), 771.

Yunus, S.R., Sanjaya, I.G.M., \& Jatmiko, B. (2013). Implementasi pembelajaran fisika berbasis guided inquiry untuk meningkatkan hasil belajar siswa auditorik. Jurnal Pendidikan IPA Indonesia, 2(1), 48-52.

Zakar, Z., \& Baykara, H. (2014). Inquiry-based laboratory practices in a science teacher training program. Eurasia Journal of Mathematics, Science and Technology Education, 10(2), 173-183.

Zimmerman, B. J. \& Schunk, D. H. (2008). Motivation: An essential dimension of selfregulated learning. In D.H. Schunk \& B.J. Zimmerman (Eds.), Motivation and selfregulated learning: Theory, research, and applications (pp. 1-30). Mahwah, NJ: Lawrence Erlbaum Associates.

Zulkarnaen, Supardi, Z.A.I, \& Jatmiko, B. (2017). Feasibility of creative exploration, creative elaboration, creative modeling, practice scientific creativity, discussion, 
reflection (C3PDR) teaching model to improve students' scientific creativity of junior high school. Journal of Baltic Science Education, 16(6), 1020-1034.

\section{Authors :}

\section{${ }^{*}$ Dr. Rizqi (Corresponding Author)}

Education Quality Assurance Agency of East Java, Surabaya, Indonesia

Jl. Ketintang Wiyata No.15, Ketintang, Kec. Gayungan, Kota SBY, Jawa Timur 60231

Email: rizqilpmp@gmail.com

\section{Prof. Dr. Prabowo}

Faculty of Mathematics and Natural Sciences,

State University of Surabaya, Surabaya

Jl. Ketintang, Surabaya 60231, Indonesia

Email: prabowo@unesa.ac.id

\section{Prof. Dr. Tjandra Kirana}

Faculty of Mathematics and Natural Sciences,

State University of Surabaya, Surabaya

Jl. Ketintang, Surabaya 60231, Indonesia

Email: tjandrakirana@unesa.ac.id 